\title{
Dos sinais às imagens poéticas: leitura de poesia e crítica do imaginário
}

\author{
From the signals to the poetic images: poetry reading and criticism of the imaginary \\ Enivalda Nunes Freitas e Souza \\ Fernanda Cristina de Campos \\ Universidade Federal de Uberlândia - Uberlândia - Minas Gerais - Brasil
}

$\diamond$

\begin{abstract}
Resumo: Este trabalho privilegia uma concepção de arte poética que capta os elementos naturais como sinais de extratos mais profundos. Ao revestir as imagens de uma carga simbólica, o poeta promove, segundo G. Bachelard, uma experiência nova com a linguagem e faz renascer um novo psiquismo, além de sobrepor mundos diversos e cruzar experiências passadas e futuras. A provocação ao desenvolvimento desse tema vem dos poemas "Poetas e insetos", "Falcões" e "As formas prisioneiras", de Dora Ferreira da Silva (1918-2006). Nessa poeta, a conversão de sinais em símbolos operada pelo texto poético encontra ressonância nas teorias de Jung e Durand, que compreendem o símbolo - resultado da cultura e das pressões subjetivas - como responsável pelo dinamismo do objeto artístico, cujo sentido é incessante. O encaminhamento desse estudo se faz por meio de análises dos poemas, conceitos sobre imagem e símbolo e de um percurso sobre a história do imaginário no ocidente.
\end{abstract}

Palavras-chave: Imagem; símbolo; Dora Ferreira da Silva; Bachelard; Jung

\begin{abstract}
This work focuses on a conception of poetic art which captures the natural elements as deeper signals of extract. By covering the images with a symbolic load, the poet promotes, according to Bachelard, a new experience with language and revives a new psychism, besides overlapping diverse worlds and crossing past and future experiences. The provocation to the development of this theme comes from the poems "Poetas e insetos", "Falcões" and "As formas prisioneiras", by Dora Ferreira da Silva (1918-2006). In this poet, the conversion from signals into symbols operated by the poetic text finds resonance in the theories of Jung and Durand, who comprehend the symbol - the result from culture and subjective pressures - as responsible for the dynamism of the artistic object, whose meaning is incessant. The development of this study is made through the analyses of the poems, concepts of images and symbol and an overview of the history of the imaginary in the West.
\end{abstract}

Keywords: Image; symbol; Dora Ferreira da Silva; Bachelard; Jung

\section{Poetas e insetos}

"O artista caminha por atalhos e desvios, longe da estrada principal. Então, ele descobre o que falta na estrada principal, o que falta aos homens", escreve Carl Gustav Jung em conferência de 1922, intitulada "Relação da psicologia analítica com a obra de arte poética" (JUNG, 1991, p. 71). É assim, sem mapas e sem roteiros, seguindo os sinais da natureza e do inconsciente, palmilhando caminhos inseguros e inusitados, zonas obscuras da imaginação, que o poeta faz ressoar por meio da palavra consciente as imagens simbólicas, estabelecendo pontes com um cotidiano admirável ou recuando a fontes longínquas do illud tempus.

Na forma de lidar com a natureza, não a reproduzindo, porém, deformando-a - já o dissera Mário de Andrade no "Prefácio interessantíssimo": todos os grandes artistas são deformadores da natureza - o poeta insere uma visada simbólica extensiva a todos os homens e assegura a perenidade da arte. Quando o poeta lança sobre sinais o fenômeno simbólico da imaginação, está fazendo da poesia um "patrimônio do imaginário da humanidade" (DURAND, 2001, p. 25). A poeta paulista Dora Ferreira da Silva (1918-2006) elabora sua poesia partindo da 
concepção de que o mundo está coberto de sinais, recados que o poeta desvela e os recobre novamente pela força psíquica da linguagem. Por isso, à primeira vista, a poesia surge como um complexo de "signos arbitrários" que, recebidos pelo leitor, sofrerão o peso de um símbolo. Veja-se como isso acontece no poema "Poetas e insetos":

Poetas e insetos
Gravamos nas folhas (como insetos)
signos arbitrários
futuros dicionários
para aprendizes de símbolos.
O céu é transparente como
as lentes dos óculos
e a terra se adorna
como as belas mulheres.
Subimos a escada platônica
descemos a escada plutônica
escrevendo entre dois amores
a modo de insetos nas folhas
para gerar sem fimoutras flores
outras fomes (SILVA, 1999, p. 137)

O signo poético ganha simbologia quando o leitor entra com a experiência subjetiva e as forças sociais que vão encorpando as palavras com a prenhez simbólica acumulada em cada época. A polissemia da linguagem poética é o dicionário ideal para quem quer aprender a olhar o mundo como um conjunto de sinais porque, uma vez a palavra convertida em símbolo, o sentido não se esgotará e a imagem nunca cessará de significar.

Céu e terra, natureza e cosmos são celeiros de símbolos, basta que, deles, o poeta se aperceba. Os encantos da terra são os rios que correm, os olhos dos lagos das florestas, as pedras e suas lições. Do céu vem a clareza que é a consciência da linguagem na ordenação do processo da escrita para que o poema continue provocando, gerando outros sentidos, bem como outras iluminações. Entretanto, apesar de sua ordenação, os signos engendrados pela natureza lançam interpretações muitas vezes ininteligíveis. Quem entende os traços do inseto na folha vegetal? Incompreensíveis são as fissuras ou trilhas tecidas pelos invertebrados. Todavia, a natureza em sua plenitude de linguagem colhe nesses sinais os seus segredos.

De igual modo, o poeta ensaia caminhos sem roteiros que ganharão possibilidades de sentidos novos a cada leitura. Nascem novas palavras e formas de linguagem, "futuros dicionários" (SILVA, 1999, p. 137), como afirma a voz poética no terceiro verso da primeira estrofe do poema. Esse é o desempenho da imaginação frente a um signo, que se desponta em imagem poderosa, cativante e dinâmica à espera de "aprendizes de símbolos" (SILVA,
1999, p. 137), como está posto no último verso também da primeira estrofe. Observa-se que a imagem literária se torna eixo essencial da criação e recepção poéticas.

Poeta e leitor participam da experiência em sua novidade trazida pela imagem reinventada pelo labor da linguagem. Ambos acessam, dialeticamente, compartimentos de mundos diferentes: "subimos a escada platônica/descemos a escada plutônica", para assim revelar o esplendor da obra, "escrevendo entre dois amores/a modo de insetos nas folhas/para gerar sem fim/outras flores/outras fomes" (SILVA, 1999, p. 137). Ao tocar as novas imagens, poeta e leitor exploram, infinitamente, outros símbolos, dinamizando a existência de outros significados, evocando sempre o potencial e a importância da imagem poética, que nem sempre foi tomada como um artífice de valor na solidificação de pensamentos e na própria criação poética. Paradoxalmente, a sociedade moderna ocidental é denominada como a civilização da imagem. Porém, desde tempos remotos, o Ocidente, calcado no pensamento socrático e cristão, combateu a utilização das imagens, renegando o valor artístico e transcendente das palavras poéticas, como bem discorre Gilbert Durand, ao empreender uma reflexão sobre a iconoclastia persistente (cf. DURAND, 1989, p. 10).

\section{O percurso do imaginário}

A crítica do imaginário foi sistematizada por Gilbert Durand (1921-2012) a partir dos trabalhos de pensadores da primeira metade do século XX que estavam interessados em cultura, religião e etnografia como possibilidades de compreender o homem pelo viés da espiritualidade. Nesse sentido, as reflexões ocorridas nos encontros em Ascona (Suíça), conhecidos como escola de Eranos, exerceram grande impacto sobre suas ideias, sobretudo o pensamento de Carl Gustav Jung (1875-1961), Mircea Eliade (1907-1986) e Gaston Bachelard (1884-1962).

Valendo-se dos estudos de arquétipo de Carl Gustav Jung, dos conceitos de homem religioso de Mircea Eliade e das reflexões sobre a imaginação dinâmica - a fenomenologia - de Gaston Bachelard, o pensador francês, Gilbert Durand, vê na forma simbólica da obra de arte uma possibilidade para o homem vencer o tempo. $\mathrm{Na}$ organização desses pensamentos, chegou-se à crítica do imaginário, pautada pelo estudo da imagem, do símbolo e do mito constituídos como eixo central da interpretação da arte como forma simbólica.

Gilberto Durand afirma que durante séculos imperou no mundo ocidental a guerra iconoclasta. Dividiu, o pesquisador, essa guerra iconoclasta em três grandes períodos: na era helênica, com os pressupostos aristotélicos; na era medieval, com a filosofia escolástica, e na era racionalista dos séculos XVII e XVIII. 
Por outro lado, prossegue Durand (1989), em defesa da valorização da imagem, trazendo um certo desequilíbrio ao iconoclasmo endêmico, surgiram vários grupos resistentes ao pensamento progressista e racionalista contrários ao imaginário. Basta lembrar como a linguagem barroca se impôs, revestindo-se de imagens, a fim de arrebatar o homem dos templos nus de estatuárias e pinturas dos protestantes.

Dentre estes grupos, os que merecem relevo são aqueles ligados ao movimento romântico - o que inclui com destaque os simbolistas. Os românticos, ao delinearem uma teoria sobre o "sexto sentido", criam uma terceira via de conhecimento com a finalidade de atingir o belo: "uma via que privilegia mais a intuição pela imagem do que a demonstração pela sintaxe" (DURAND, 1989, p.32). As reflexões sobre o "juízo de gosto" de Kant; os sistemas filosóficos de Schelling, Schopenhauer e Hegel. As inovações estéticas na poesia baudelairiana representaram verdadeiras insurreições e resistências à guerra iconoclasta. A imagem recupera seu status, passa a ser o ponto central para as análises estéticas e a arte liberta-se "aos poucos dos serviços antes prestados à religião e, nos séculos XVII e XIX, à política" (DURAND, 1989, p. 32).

Durand não se esquece da enorme contribuição de Sigmund Freud (1856-1939) aos estudos da imagem. Foi este quem revelou que as imagens são mensagens "que afloram do fundo do inconsciente do psiquismo recalcado para o consciente. Qualquer manifestação da imagem representa uma espécie de intermediário entre o inconsciente não manifesto e uma tomada de consciência ativa" (DURAND, 1989, p. 32). A imagem não apenas se torna a "Rainha das faculdades" (título dado por Baudelaire) como se transforma em instrumento primordial que dará acesso aos compartimentos mais isolados e recalcados do psiquismo.

Gilbert Durand (1989, p. 36) constata que a valorização da imagem alcança o apogeu com os estudos do psiquiatra Carl-Gustav Jung, que reinterpreta a imagem, pluralizando o seu conceito. Jung liberta a imagem, desconstruindo a ideia de concepção única, obsessiva e totalitária da libido, transformando as imagens em estruturas plurais que compõem as estruturas do imaginário. As palavras poéticas revelam esquemas arquetípicos do artista, como de todo o imaginário coletivo, e na plurissignificação serão as traduções arcaicas e espirituais do sujeito e da cultura, segundo o psiquiatra.

A partir da valorização das imagens, o poeta ganha o título de artista maldito, visionário, profeta, mago e guia. A imagem passa a ser reconhecida em suas ambiguidades e dobras, o que possibilitou as inúmeras maneiras de representar a realidade por meio das análises poéticas e dinâmicas das palavras.
Conclui-se, então, que tal possibilidade de estudo da imagem em seu campo simbólico faz ampliar até mesmo o conceito de mímesis clássica, como afirma Luiz Costa Lima ao discorrer sobre a representação moderna no capítulo intitulado "A explosão das sombras: mímesis entre os gregos":

o discurso mimético é uma das formas do discurso do inconsciente, o qual só é reconhecido como artístico quando o receptor encontra no texto uma semelhança com a própria situação histórica. A situação histórica funciona, portanto, como um possibilitador do significado que será alocado no texto. A obra, enquanto tal, é um significante a que o leitor empresta um significado. Ela permanece tomada como artística enquanto a situação histórica permite a alocação de um significado ficcional, sendo próprio do ficcional permitir descoberta, na alteridade da cena do texto, de uma semelhança com a cena dos valores de quem o recebe. Esta conclusão torna, pois, forçoso o desenvolvimento, aqui não praticado, do conceito de ficção e de seu papel nas sociedades humanas como agenciador de imaginário (LIMA, 2003, p. 81)

O estudo das imagens possibilita o trânsito pelo trajeto antropológico do poeta e o contato com seu imaginário, concedendo ao leitor inserção na criação poética. Assim como o poeta pôde selecionar e acessar as imagens, libertando-as de seu estado denotativo e de inércia, os leitores, por meio do devaneio poético, também, têm a autonomia de libertar as formas prisioneiras. $\mathrm{Na}$ fruição, as imagens são tocadas, são interpretadas e, como afirma Costa Lima, o leitor acessa o inconsciente do poeta com o seu próprio inconsciente. Há um imbricamento de arquétipos, mistura de experiências pessoais e de situações históricas por meio das releituras das imagens poéticas.

\section{Um falcão peregrino}

O poema seguinte de Dora Ferreira da Silva percorre uma imagem - a de um pássaro - carregando-a de força simbólica. Os primeiros versos, "Povoa-se o mundo de sinais / dizeres mudos" (SILVA, 1999, p. 272), anunciam a imagem de um falcão peregrino entrando pela varanda de uma casa, desencadeando um fio de associações que enlaçam a contemporaneidade do sujeito poético à Idade Média (Dama de Cluny) e ao Egito de Hórus e Akhenáton.

\section{Falcões}

Povoa-se o mundo de sinais dizeres mudos. $\mathrm{O}$ falcão peregrino entra na vivenda assustando a esposa de Marino. Desvia os olhos límpidos que espelharam faraós dinastias templos jardins claríssimos dias.

Outro falcão - mais feliz - comeu nas mãos gentis da dama de Cluny. Agora aqui 
passa em bando clandestino

à procura do Sol de outro destino.

Hórus - falcão peregrino - é um filho bastardo de Ísis e talvez de Osíris. Em coro os deuses até hoje discutem.

No jardim espreito o falcão peregrino

em busca de terra mais quente

de ombro mais fino. Exilou-te Akhenáton porque eras só meu

e em teu olho redondo eu mirava em espelho.

Mais tarde - em Cluny - afaguei teu contorno

tuas plumas tecidas então se aqueciam. O porteiro grognon

impaciente dizia: - Alors, Il faut partir!

Enredada num fio, a ti me prendia.

Povoa-se o mundo de sinais

dizeres mudos. (SILVA, 1999, p. 272)

O impulso de voar e peregrinar do falcão suscita toda uma simbologia da alma humana que não encontra morada na terra, vivendo em perpétuo caminhar por tempos e lugares distantes, acordando lembranças vividas e imaginadas e alimentando a nostalgia de um tempo feliz que não conheceu. Ao pássaro imponente, mas solitário, agrega-se a imagem do bastardo, Hórus, estreitando mais ainda a aproximação simbólica entre homem um amaldiçoado - e pássaro peregrino. A inicial mudez simbólica do signo - um pássaro invadindo um recinto e assustando a moradora - se avoluma na estrofe seguinte quando o sujeito poético atravessa um espelho - o olho do falcão - e se faz contemporâneo do tempo dos faraós e da Dama de Cluny.

No tempo em que não se valoriza ler os sinais - a contemporaneidade, dessacralizada, e o tempo do Faraó Akhenáton, que expulsou todos os videntes do reino - o sujeito poético assume o papel da sibila que compreende os sinais da natureza. Em outra era e espaço, um elemento profano - um porteiro impaciente - desfaz o encanto, cortando o fio da imaginação, quando o sujeito poético admirava a tapeçaria, enredado por ela.

É observando o falcão de sua varanda que o sujeito poético divaga sobre tempos remotos que se presentificam pela força do símbolo. As imagens se fundem a partir do "Agora aqui" da ave em bando mas que se afigura sozinha. Nos "olhos límpidos que espelharam faraós dinastias / templos jardins claríssimos dias" (SILVA, 1999, p. 272), o sujeito poético reconhece-se dono do falcão já no tempo do faraó que extinguiu os cultos religiosos e, bem mais tarde, em Cluny, como a dama que lhe afaga as penas, ao contemplar a tapeçaria.

O anúncio do mundo como revelação, no começo do poema, é estabelecido pelo movimento das imagens dos versos seguintes que arrastam o leitor para tempos e espaços distantes. A construção imagética cruza rapidamente com um acontecimento prosaico, também elaborado prosaicamente, com imagens de tomada mais poética, como olhos, faraós, jardins, espelhos, tapeçarias, que vêm como "desvio" da linguagem anterior, uma vez que a ausência de vírgulas acompanha o olhar global do falcão que vê com nitidez os elementos misturados pela visão abrangente.

A finalização do poema, com os mesmos dois versos iniciais, leva a compreender o movimento da imagem do falcão como uma dinâmica simbólica com capacidade projetiva para outras formas de arrebatamento da temporalidade. A imagem tecida no poema, plena de realidade psíquica, encerra tantos outros sinais de transporte afetivo e faz o leitor recuar-se no tempo ou projetar-se no devir.

Uma imagem - a do falcão e os contextos em que se insere - evoca o mistério da existência humana cuja indagação é sempre acolhida pela palavra poética. Em plena consciência do ato criador, a poeta reinventa a imagem do pássaro mítico que, tal como o homem, movimenta-se face à vida, em busca de seu lugar ao Sol: "Agora aqui / passa em bando clandestino / à procura do Sol de outro destino" (SILVA, 1999, p. 272). Colocada à procura de um destino, a imagem do falcão antropomorfiza-se, ganha nova forma e novo sentido. Portanto, observa-se que a poeta extrai da cultura e de sua percepção apenas um impulso de matéria poética, uma imagem que foi trabalhada para se libertar da imagem de um simples falcão ou pássaro.

\section{0 arquétipo, o poeta e o símbolo}

A função do inconsciente que envia recados símbolos - ao consciente foi verificada por Jung, que ficou intrigado com os desenhos de seus pacientes, que engendravam figuras circulares, as mandalas, como se tivessem recebido instrução para aquilo. O estudioso logo entendeu que os desenhos tinham uma carga simbólica, isto é, o homem é capaz de produzir símbolos por meio do sonho e da arte, que é quando se manifesta em toda sua pregnância simbólica. Não demorou para que Jung visse naquelas figuras símbolos de uma intuição compartilhada pela humanidade, o que o levou a sistematizar a teoria do inconsciente coletivo. Além de um inconsciente individual, composto por informações traumáticas, recordações, influência cultural, que ficaram adormecidos no inconsciente, o homem também dispunha de um inconsciente coletivo, imagens que se manifestavam indistintamente em todos os homens, ao que ele denominou de arquétipo: "a imagem arquetípica constitui um correlato indispensável da ideia de inconsciente coletivo, indica a existência de determinadas formas na psique, que estão presentes em todo tempo, em todo lugar" (JUNG, 2008, p. 53). 
Jung escreve que as imagens arquetípicas são, na verdade, possibilidades de ideias, e que o inconsciente coletivo não é reprimido nem esquecido: "A rigor, o inconsciente coletivo nem existe, pois nada mais é do que uma possibilidade, ou seja, aquela possibilidade que nos foi legada desde os tempos primitivos na forma de imagens mnemônicas. Ideias inatas não existem. Existem possibilidades inatas de ideias" (JUNG, 1991, p. 69). Segundo Jung, imagem primordial (arquétipo) é uma figura "que reaparece no decorrer da história, sempre que a imaginação criativa for livremente expressa. É, portanto, em primeiro lugar, uma figura mitológica" (JUNG, 1991, p. 69). O arquétipo é sempre invariável, o que transforma é o símbolo, quando o homem entra em contato com as forças sociais.

O poeta deverá encontrar o símbolo adequado e novo para expressar o arquétipo. As imagens arquetípicas contêm extratos profundos da psique, por isso portam "psicologia e destino humanos" - dor e prazer, por exemplo. Então, o que é individual, é alçado ao "destino da humanidade", e o que é da categoria do "único e efêmero" se projeta no "contínuo devir". Assim, quando o poeta deixa fluir uma imagem arquetípica, a obra de arte entra como fator de equilíbrio social, encontrando nos caminhos menos palmilhados uma resposta ou provocação para seu tempo: "É aí que está o significado social da obra de arte: ela trabalha continuamente na educação do espírito da época, pois traz à tona aquelas formas das quais a época mais necessita" (JUNG, 1991, p. 70, 71).

Jung finaliza a conferência de 1922 acentuando o processo a que o artista se entrega para transformar a imagem arquetípica "até que ela possa ser compreendida por seus contemporâneos" (JUNG, 1991, p. 71). Trata-se, portanto, da criação do símbolo, assim definido:

O que chamamos de símbolo é um termo, um nome ou mesmo uma imagem que nos pode ser familiar na vida diária, embora possua conotações especiais além do seu significado evidente e convencional. Por isso uma palavra ou uma imagem é simbólica quando implica alguma coisa além do seu significado manifesto e imediato. Esta palavra ou esta imagem têm um aspecto "inconsciente" mais amplo, que nunca é precisamente definido ou de todo explicado (JUNG, s/d, p. 21).

Cabe ao artista revigorar os símbolos, criar imagens que mantenham a "pregnância simbólica", a peso de transformar um símbolo num "sintema", um mero sinal, sem nenhum distanciamento do objeto evocado. Gilbert Durand teoriza como funciona o símbolo:

O simbolismo só "funciona" se existe distanciação, mas sem corte, e se há plurivocidade, mas sem arbitrariedade. É que o símbolo tem duas exigências: deve medir a sua incapacidade para "por à vista" o significado em si, mas tem que comprometer a crença na sua pertinência total (DURAND apud ALLEAU, 1976, p. 26).

Gilbert Durand pontua sobre a confusão dos termos relativos ao imaginário, fato que se deve, segundo ele, à desvalorização da fantasia no ocidente. Para chegar ao símbolo, o signo "viúvo" do significado, Durand passa pela imagem, pelo signo e pela alegoria. Em relação ao significante, enquanto o signo é arbitrário e adequado, e a alegoria é não-arbitrária e, parcialmente adequada, o símbolo é não arbitrário, não convencional e inadequado por excelência. A relação do signo entre significante e significado é de equivalência, ao passo que a da alegoria é de tradução (caveira e foice apontam para morte) e a relação do símbolo entre significante e significado é de epifania, epifania de um mistério. O símbolo não é uma representação direta e seu significado nunca é dado fora do processo simbólico. (cf. DURAND, 1988, p. 17).

Valendo-se de Paul Ricoeur, Durand assinala as três dimensões do símbolo: a cósmica, pois o símbolo liga-se ao mundo que nos rodeia; a onírica, pois os símbolos ligam-se a recordações que emergem nos nossos sonhos (Freud) e a poética, pois é produto da linguagem (cf. DURAND, 1988, p. 12). Há que se lembrar, ainda, do caráter polivalente, ambíguo e até contraditório do símbolo. A inesgotável epifania do símbolo é consequência de sua "repetição instauradora": o símbolo nunca é explicado uma vez por todas. A repetição o aperfeiçoa, as várias leituras de um símbolo vão esclarecendo um outro símbolo.

A imagem é uma maneira indireta que o consciente dispõe para representar o mundo, quando "a coisa não pode apresentar-se "em carne e osso" à sensibilidade, como na recordação da nossa infância" (DURAND, 1988, p. 7). Na poesia, Octavio Paz salienta a intraduzibilidade da imagem: a imagem não quer dizer, ela diz; a imagem é o próprio sentido. Quando explicada, ela perde a sua riqueza. Se na prosa há várias maneiras de se dizer uma coisa, na poesia há só uma. Desta forma, a linguagem perde sua "mobilidade": "a linguagem, tocada pela poesia, cessa imediatamente de ser linguagem. (...) O poema transcende a linguagem" (PAZ, 1982, p. 134, 135).

\section{Um jardim de formas prisioneiras}

Gaston Bachelard afirma que toda imagem literária em sua novidade torna-se um texto original da linguagem, uma tessitura poética nova. Portanto, o poeta e também o leitor devem conceber a imaginação como a "faculdade de deformar as imagens fornecidas pela percepção" (BACHELARD, 2001, p. 1), porque imaginar "é sobretudo a faculdade de libertar-nos das imagens primeiras, de 
mudar as imagens. Se não há mudança de imagens, união

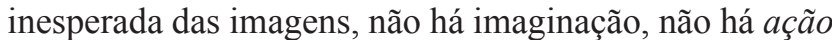
imaginante" (BACHELARD, 2001, p. 1).

O poema intitulado "As formas prisioneiras...", de Dora Ferreira da Silva, caminha artisticamente na direção de Bachelard, visto que sua temática discute sobre a possível libertação (deformação) da matéria - toda a cosmologia e, por extensão, os conteúdos inconscientes - pela força redentora da imagem, ou seja, pela criação poética:

\author{
As formas prisioneiras... \\ As formas prisioneiras por belas e dementes \\ esperam seu resgate. Nem veriam \\ a eclosão \\ essas duras crisálidas do sono \\ ocultas em pedras, telas, tramas, \\ insensíveis ao sol, à chuva fria, \\ nem júbilo \\ nem melancolia \\ sem que as desates. \\ Medram a medo \\ na ante-manhã, carentes de teu sonho, \\ princesas embalsamadas em sucessão estranha, \\ à espera (SILVA, 1999, p. 61).
}

O título prediz aquilo que o poema é antes mesmo de nascer. Trata-se do ante-poema, a não-composição, aquilo que as palavras são antes de sua organização como linguagem poética, isto é, um arquétipo, uma forma encarcerada em estado primordial. Observa-se um poema composto por treze versos livres, cujo ritmo semântico é determinado por enjambements que tematizam em camufladas assertivas metalinguísticas, o processo de elaboração poética bem como a sondagem de uma situação psicológica.

No primeiro verso, destacam-se os atributos dessas formas: belas e dementes, adjetivos que, semanticamente, opõem-se, mas que se aproximam, por meio da dialética, definindo as formas. Tratam-se de particularidades fortes que revelam a natureza complexa das imagens. No segundo verso, marcado pelo enjambement, percebe-se a inércia dessas formas à espera de um possível resgaste: "As formas prisioneiras por belas e dementes/esperam seu resgaste" (SILVA, 1999, p. 61).

O jogo imagético evocado ao longo poema é o desejo de liberdade das palavras, que remete à discussão essencial do fazer poético. É preciso que haja a libertação das formas, para que as mesmas se organizem em linguagem na folha em branco de papel. Não é à toa que ao final do título revelam-se as reticências, que induzem o desejo libertário.

Não há outro caminho para a libertação das formas prisioneiras que não seja através da pena do Poeta. $\mathrm{O}$ poema em análise - como os demais estudados neste artigo - é um convite à reflexão sobre o processo de elaboração poética. Para cada análise de poema, toma-se, como ação primeira, a verificação das imagens, levando ao entendimento e intimidade de cada uma, o que resultará na compreensão do imaginário que envolve o poeta. Assim, entender as imagens é o primeiro passo para o processo de libertação das palavras.

Ainda nos mesmos versos, "As formas prisioneiras por belas e dementes/esperam seu resgate" (SILVA, 1999, p. 61), observa-se que não se trata somente da libertação por parte do poeta. A recepção da poesia está em jogo, uma vez que o leitor também se transforma em ser criante ao participar, por meio de releituras, do resgate das imagens poéticas. $\mathrm{O}$ poeta foi o primeiro, em ritual órfico, a adentrar nos mundos ínferos da imaginação, com o objetivo de resgatar as palavras, transformando-as em seres vivos. No segundo momento, há um outro resgate, dado por meio da leitura, tão impressionante como o primeiro, pois o leitor, ao passo que toca as imagens com o olhar, voz e ouvido, ressuscita-as, trazendo-as para o seu mundo, deformando-as com o seu imaginar.

O lirismo engendrado por Dora Ferreira da Silva é um convite ao reino da criação poética, a fim de que seja vislumbrado o ante-poema, uma vez que o mesmo se encontra em plena maturação, sendo "essas duras crisálidas do sono" (SILVA, 1999, p. 61). Comparadas às borboletas em seu terceiro estado de desenvolvimento, ou seja, aquilo que ainda não é uma borboleta, mas virá a ser, as palavras em seu estado amorfo encontram-se "ocultas em pedras, telas, tramas,/insensíveis ao sol/à chuva fria" (SILVA, 1999, p. 61). São ainda frágeis, mas encerram o poder da imaginação, do processo criante tanto do poeta quanto do leitor que as despertam - o primeiro por meio da escrita e o segundo por meio da leitura.

Outra imagem bela e forte evocada no poema é a das princesas embalsamadas, que comungam e dialogam tão bem com a imagem da crisálida. Somente uma imaginação dinâmica e aberta para relacionar as borboletas a princesas embalsamadas, visto que a crisálida é o corpo da borboleta em seu desenvolvimento ocorrido sob a casca dura, como se a crisálida estivesse embalsamada, como as princesas, antes de nascer.

Finalmente, a casca se rompe e, então, nasce a borboleta, a palavra encantada. Percebe-se que a imagem da crisálida repousa na metáfora das princesas embalsamadas que estão à espera do vir a ser, pois do nascimento há o anseio da vivência, sendo ela repleta de júbilo ou de melancolia. O que importa é o nascimento para as futuras experiências, sendo as mesmas boas ou ruins: "nem júbilo/nem melancolia/sem que as desates./ Medram a medo/na ante-manhã, carentes de teu sonho" (SILVA, 1999, p. 61). 
Seguindo o viés metalinguístico, o poema evoca a mesma ideia do "mundo povoado de sinais" à espera do gesto revelador da palavra poética. A poesia dá voz à matéria muda e pesada, liberta em versos o movimento aprisionado na "floresta de símbolos" que reconhece o homem, mas o homem não a reconhece, escreve Baudelaire em "Correspondências" (cf. BAUDELAIRE, 1985, p. 115). A palavra que vê o que os outros não veem é a palavra inaugural, fundante, que se encarrega de sentidos múltiplos, sem jamais se esgotar, tal é a força da imagem. Ao ler os versos de Andanças (1970), livro que guarda esse poema, o amigo Carlos Drummond de Andrade escreve a Dora Ferreira da Silva: "Suas Andanças estão aqui, andantes, dançantes, libertando em música as 'formas prisioneiras', numa contínua criação de poesia" (SOUZA, 2013, p. 39). Assim, a poesia faz acontecer, confirmando o vir-a-ser da linguagem.

As coisas passam a existir depois de sua nomeação. Antes, vivem num sono profundo, como que encantadas em eterna "ante-manhã", às portas da palavra libertadora que imprimirá emoção. "Crisálidas", "princesas embalsamadas" reivindicam a ideia de transformação e de um certo suplício com que se paga a espera da libertação, a qual implica em um sonhar muito correlato ao devaneio bachelardiano. Para tirar a palavra de seu uso comum, é preciso pensá-la. Bachelard dialoga com Paul Valèry e sua observação de como se passa rapidamente por sobre as palavras. No cotidiano, esta é a salvação do homem, porque se demora sobre as palavras, cai-se em armadilhas e embaraços. (cf. BACHELARD, 2001, p.47). O sonho do poeta é o devaneio e sua função é "chocar" as palavras familiares: "Então, a eclosão mais inesperada, mais rara, sai da palavra que dormia no seu significado - inerte como um fóssil de significações" (BACHELARD, 2009, p. 18).

\section{Por debaixo do jardim: uma forma prisioneira}

Estar atento às imagens criadas pelo poeta é acessar seus arquétipos mais profundos. Diante do poema, deve-se tomar as imagens em estado de origem e beneficiar-se delas como se as mesmas fossem o produto psíquico da imaginação do poeta a ser estudado. É por isso que para Bachelard a imagem poética vai além da simples metáfora. Ela, realmente, abre-se para instintos recalcados, para as pistas que conduzem ao trajeto antropológico do poeta. Desta forma, deve-se tomar a imagem como um novo ser da linguagem, centro da criação poética, superior a qualquer outra forma estilística engendrada (cf. BACHELARD, 2009, p. 3,4).

O poema "As formas prisioneiras..." avança os limites metalinguísticos e se abre para a sugestão de um acontecimento psíquico que pode ser relacionado aos conteúdos arcaicos que estão aprisionados e adormecidos no indivíduo, à espera de transformação em matéria consciente. É o entregar-se ao universo do poeta em devaneio poético que resulta em eclosão de imagens em que os conteúdos aprisionados passam por uma assimilação racional, deixando de ser insensíveis e sombrios. Resgatar as formas prisioneiras sugere, portanto, o processo de individuação que deve trazer à luz aspectos obscuros da personalidade e incorporá-los ao campo psíquico.

Segundo Jung, o arquétipo da sombra é o que mais perturba o eu, e tomar consciência da sombra significa reconhecer os aspectos obscuros da personalidade, atitude indispensável para qualquer processo de autoconhecimento. Esse processo é muito demorado e doloroso, mas é terapêutico. Jung deixa claro que o arquétipo da sombra está relacionado às projeções, que são de natureza emocional, e com uma certa "autonomia", uma vez que a emoção é um evento que sucede a um indivíduo, exigindo dele uma força de vontade que ele não possui, até mesmo porque acredita que a emoção parece provir "de outra pessoa" (JUNG, 1986, p. 7). Sem dar cidadania ao sombrio, por medo e insegurança, o sujeito se isola do mundo exterior e vive uma ilusão, isto é, sua relação com o real é ilusória.

Para a construção da imagem poética que gira em torno da ideia de transformação - pela linguagem das palavras ou pela conscientização de conteúdos obscuros há uma constelação simbólica de imagens que vão tecendo o campo semântico, cujos símbolos mais contundentes são "eclosão, "crisálida" e "embalsamadas". Nem o ato de escrever nem a tomada de consciência são processos simplificados. É preciso incorporar elementos díspares, como "júbilo" e "pedra" para que "as formas prisioneiras" saltem da "ante-manhã" para a iluminação da palavra poética e da consciência.

$\mathrm{O}$ inconsciente se afigura como uma "princesa adormecida", portanto, à espera do toque mágico da palavra e do reconhecimento pelo campo psíquico. Vale lembrar que o inconsciente é, segundo Jung, governado por anima, que é responsável, inclusive, pela criação artística. A ante-sala da realização artística e psíquica evoca, ainda, um segundo espaço feminino, o jardim, fonte mítica da origem da vida e símbolo de prazeres, intimidade e aconchego em todas as culturas. $\mathrm{O}$ jardim terrestre é um espaço sagrado que recorda ao homem a ideia do Paraíso, com a diferença que ele é criador de seu jardim, é o doador da vida que se oculta entre "pedras", "telas", "tramas", "sol", "chuva". Por baixo da camada superficial, há flores belas a desatar. A paronomia instaurada no verso "medram a medo" acentua o exigente processo da construção do espaço psíquico, sedimentado em disparidades e solidão. 
O último verso, "à espera", recebe um teor provocativo ao se destacar sozinho para encerrar o poema, unindo o princípio ao fim, reafirmando, portanto, que as formas prisioneiras estão esperando o resgate. Dora Ferreira da Silva concebia a linguagem poética como reinauguradora da vida, acreditava em sua potência de nomear a realidade fundando-a; conhecia, também, a fundo o pensamento de Jung, uma vez que coordenou os trabalhos de tradução do psicólogo aqui no Brasil. Contudo, a primeira tradução que fez do psicólogo das profundezas, Memórias, sonhos e reflexões, foi publicada em 1975, cinco anos depois da publicação desse poema.

\section{0 poeta e a imagem poética}

Segundo Gaston Bachelard, em seu livro A poética do devaneio, a imagem exige um método especial de análise denominado de método fenomenológico das imagens poéticas, que parte do seguinte pressuposto: as imagens são o germe da poesia e do mundo imaginante. Por isso, faz-se necessário conduzir o leitor a uma comunicação com a consciência criante do poeta a partir do contato com as imagens: "escolhi fenomenologia na esperança de reexaminar com um olhar novo as imagens fielmente amadas, tão solidamente fixadas na minha memória que já não sei se estou a recordar ou imaginar quando as reencontro em meus devaneios". (BACHELARD, 2009, p. 3,4$)$.

Analisar as imagens é submergir na produção psíquica do poeta, compactuando-se com a imaginação do escritor. O labor poético é o melhor destino para essas formas prisioneiras que anseiam a liberdade que se eterniza em versos, sensações, ideias e invariáveis alusões a mundos diversos. Cada imagem-poética resgatada, despertada, "em sua novidade, abre um porvir de linguagem" (BACHELARD, 2009, p. 3,4) no devaneio poético.

O método fenomenológico de Gaston Bachelard coloca o leitor frente a frente com o poema, e com um momento totalmente novo, uma vez que o incentiva aprofundar-se no reino das palavras poéticas sem que estas venham como produto de recalque ou fruto de um biografismo, porque a imagem é de "uma origem absoluta" e nela está o "germe de um mundo": "a imagem não é fruto de recalque, ela não tem passado. É uma conquista positiva da palavra" (BACHELARD, 2009, p.3,4). É a condição de novidade da imagem que transporta o homem às profundezas de sua origem. Por isso, a imagem está acima de qualquer significante, cabendo a ela revigorar a língua, além de enriquecer o pensamento. E o método fenomenológico consiste em "tentar restituir no leitor a ação inovadora da linguagem poética" (BACHELARD, 2009, p. 4)
Percebe-se que o poema "As formas prisioneira..." é um convite a uma viagem ao imaginário do poeta. Imagens novas envolvem poeta e leitor em uma experiência dinâmica na criação poética, intitulado como um psiquismo novo. Adentrar neste mundo criante requer uma tomada de consciência, que é o ato de interpretar as palavras poéticas revivendo-as. Trata-se de um "devir psíquico vigoroso, um devir que propaga seu vigor por todo o psiquismo" (BACHELARD, 2009, p.5) em estado pleno, "buscando aumentar a linguagem, criar a linguagem, valorizar a linguagem, amar a linguagem" (BACHELARD, 2009, p. 3), acrescendo assim, ao poema, a intimidade de quem o analisa a partir do devaneio poético do escritor.

Bachelard explica que esta palavra devaneio é bastante complexa para quem almeja tomar consciência sobre algo, como é exigido no método fenomenológico. Isso porque a definição do próprio vocabulário devanear é esquivar-se do real, o que é negar, paradoxalmente, a tomada de consciência. Sendo assim, o devaneio vai contra toda a essência da fenomenologia, que é revestirse de conhecimento a respeito das coisas e do mundo. Todavia, um adjetivo, como afirma o filósofo da imagem, redime todo o conceito empreendido por ele. Trata-se do adjetivo poético que recria e dinamiza o conceito original de devaneio: "devaneio poético, um devaneio que a poesia coloca na boa inclinação, aquela que uma consciência em crescimento pode seguir. Esse devaneio é um devaneio que se escreve, ou que pelo menos, se promete escrever" (BACHELARD, 2009, p. 5).

O devaneio poético é a criação da palavra em potência, em ação dinâmica. Trata-se do trabalho árduo com a linguagem que desperta e harmoniza as imagens por meio da polifonia dos sentidos. Sendo assim, o devaneio poético antecede a escrita no estado de sonho acordado e culmina com a tessitura poética - a libertação e ordenação das palavras na folha de papel em branco. O poeta comunica o seu devaneio escrevendo-o com emoção, com gosto, revivendo-o melhor ao transcrever "a matéria noturna esquecida na claridade do dia" (BACHELARD, 2009, p. 10).

Dora Ferreira da Silva, em uma entrevista a Donizete Galvão, afirmou que desde pequena esteve em estado de criação poética: "A minha imaginação sempre foi grande. Não só a de olhos fechados, mas sobretudo a de olhos abertos" (GALVÃO, 2015). Esse sonhar de olhos abertos mencionado pela poeta é quando todos os sentidos despertam e se harmonizam no devaneio poético. O poeta vê-se emaranhado nessa polissemia de sentidos e é impulsionado pelas imagens a engendrar um mundo para elas. Assim, quando se lê no poema de Dora o verso "na ante-manhã, carentes de teu sonho" (SILVA, 1999, p. 61), depara-se com as imagens conclamando o toque do autor por meio do devaneio poético. 
Bachelard adverte para não confundir o devaneio poético com a inspiração, pois esta é destituída de dinamismo e "demasiado genérica para exprimir a originalidade das palavras" (BACHELARD, 2009, p. 7), transformando o engenho poético em um ato pobre e sem autonomia. Enquanto que o devaneio poético depende exclusivamente da perspicácia do trabalho do poeta e do leitor ao se depararem com as imagens. No devaneio poético há uma tomada de consciência dinâmica sobre as imagens e estas promovem a construção, a partir da originalidade e do labor poético, de outros mundos - uma válvula de escape para as hostilidades do mundo real: "o devaneio poético é um devaneio cósmico. É uma abertura para um mundo belo, para mundos belos. Dá ao eu um não-eu (...) É esse não-eu meu que encanta o eu sonhador e que os poetas sabem fazer-nos partilhar" (BACHELARD, 2009, p. 13). O ser humano é obrigado, pelas exigências da sua existência, a adaptar-se às hostilidades da vida real, a constituir-se como um ser calcado no real, mergulhado no tempo profano, porém, o devaneio poético transformase em veículo de fuga para outras realidades.

\section{Poetas, insetos, falcões}

Dora Ferreira da Silva no poema "Poetas e insetos" nivela a existência do poeta com a do inseto, sugerindo uma condição insignificante que se atribui àquele enquanto agenciador de um conhecimento que foge ao pensamento racional. A partir de tal comparação, concluise que é no desvio e na insignificância dos sinais que ainda medram em sua pré-existência, elaborados em uma linguagem que jamais esgota suas simbologias, tal qual os traços dos insetos nas folhas, que o poeta confere à arte um valor social, por converter caminhos incertos em possibilidades afetivas e transcendentes.

Os símbolos, mesmo enclausurados, como no poema "As formas prisioneiras...", esperam pelo manejo do trabalho da arte poética, o qual se revelará em eclosão de imagens a partir da tessitura do poeta e do alcance do leitor. Nessa explosão de sentidos, vê-se a riqueza da imagem que se oferece como possibilidade de conhecimento para o que ainda não foi explicado pelo pensamento racional.

A imagem poética, antes considerada como a louca da casa, pode ser comparada àquele falcão peregrino que perturba a rotina de um ambiente, desviando os olhares para mundos insuspeitáveis, uma vez que perverte a observação do sujeito poético. Com sua cultura e afetividade, o poeta atribui-lhe inesgotáveis valores simbólicos. Compreende-se, desta forma, o temor à imagem alimentado durante séculos, devido ao seu poder de desordenar a clareza das ideias e perturbar aquilo que é aparentemente dominado pelo homem.
As imagens altamente elaboradas têm o poder de alterar conceitos outrora impregnados na sociedade. "A criação é um gesto espiritual”, assim observou Mircea Eliade a respeito de Os Lusíadas, ao afirmar que é o poeta Luís de Camões quem transforma o mar em uma imagem afetiva, elemento primordialmente intimidante, ao conferir à obra um sentido espiritual que recoloca o homem em relação a seu meio. Eliade afere um sentido espiritual à obra artística:

Chegar a uma tal significação espiritual é chegar a um valor ecumênico, é transformá-lo num objeto de circulação universal - ou fazer dela um instrumento de civilização e de dignidade humana [...]. O Oceano com todos os seus mistérios, com os seus encantos escondidos, com a sua beleza, tinha sido até Camões um 'objeto' sem significação espiritual (ELIADE, 2000, p. 59)

Como foi escrito no início deste artigo, os grandes poetas são deformadores da natureza, o que assegura perenidade à obra artística e uma comunhão eterna entre os tempos. A potência humanizadora da arte apontada por Eliade é correlata à função da poesia entrevista por Jung, que lhe atribui o papel de promotora do equilíbrio social, por mais desconcertantes que sejam suas imagens, pois são elas que libertam o homem de sua hostil realidade neste mundo carente de sinais.

\section{Referências}

ALLEAU, René. A ciência dos símbolos. Trad. Isabel Braga. Lisboa: Edições 70, 1976.

BACHELARD, Gaston. A água e os sonhos. Trad. Antonio de Pádua Danesi. São Paulo: Martins Fontes, 2002.

. A poética do espaço. Trad. Antonio de Pádua Danesi. São Paulo: Martins Fontes, 1988.

. A poética do devaneio. Trad. Antonio de Pádua Danesi São Paulo: Martins Fontes, 2009.

O ar e os sonhos. Trad. Antonio de Pádua Danesi. São Paulo: Martins Fontes, 2001.

BAUDELAIRE, Charles, As flores do mal. Trad. Ivan Junqueira. Rio de Janeiro: Nova Fronteira, 1985.

DURAND, Gilbert. A imaginação simbólica. Trad. Eliane Fittipaldi Pereira. São Paulo: Cultrix, 1988.

As estruturas antropológicas do imaginário. Trad. Hélder Godinho. São Paulo: Martins Fontes, 2001.

Campos do imaginário. Trad. Maria José Batalha Reis. Lisboa: Instituto Piaget, 1998.

O imaginário. Ensaio acerca das ciências e da filosofia da imagem. Trad. Renée Eve Levié. Rio de Janeiro: Difel, 1993.

O universo do símbolo. In: ALLEAU, René. A ciência dos símbolos. Trad. Isabel Braga. Lisboa: Edições 70, 1976. p. 252-267.

ELIADE, Mircea. Camões e Eminescu. Trad. Anca Ferro. Bucareste: Libra, 2000. 
GALVÃO, Donizete. Entrevista: Dora Ferreira da Silva. Disponível em: <http://www.jornaldepoesia.jor.br/dgp5.html>. Acesso em: 05 fev. 2015.

JUNG, C. G. O homem e seus símbolos. Trad. Maria Lúcia Pinho. 7. ed. Rio de Janeiro: Nova Fronteira, [s/d.].

Os arquétipos e o inconsciente coletivo. Trad. Dora Ferreira da Dora Ferreira da Silva, Maria Luiza Appy. Petrópolis: Vozes, 2008.

Psicologia e poesia. In: $O$ espírito na arte e na ciência. Trad. Dora Ferreira da Silva, Ruben Siqueira Bianchi. Petrópolis: Vozes, 1991.

Aion - estudos sobre o simbolismo do simesmo. Trad. Pe. Dom Mateus Ramalho Rocha. Petrópolis: Vozes, 1986.
LIMA, Luiz Costa. Mímesis e modernidade: formas das sombras. Graal, São Paulo, 2003.

PAZ, Octavio. O arco e a lira. Trad. Olga Savary. Rio de Janeiro: Nova Fronteira, 1982.

SILVA, Dora Ferreira da. Poesia reunida. Rio de Janeiro: Topbooks, 1999.

SOUZA, Enivalda Nunes Freitas. Flores de Persófone: a poesia de Dora Ferreira da Silva e o sagrado. Goiânia: Cânone Editorial; Belo Horizonte: FAPEMIG, 2013.

Recebido: 03 de fevereiro de 2016. Aprovado: 01 de setembro de 2016.

Contato: eni@ufu.br 